\title{
Local Literature in Coastal Pesantren as an Alternative on Literary Reading Subject for Students of PBSI Unissula
}

\author{
Evi Chamalah', Agus Nuryatin'², Suminto A. Sayuti ${ }^{3}$, Ida Zulaeha ${ }^{4}$ \\ Graduate School, Universitas Negeri Semarang ${ }^{1}$, Lecturer of Sultan Agung Islamic University ${ }^{1}$, Professor of \\ Humanities of Universitas Negeri Semarang ${ }^{2}$, Professor of humanities of Universitas Negeri Yogyakarta ${ }^{3}$, \\ Professor of Linguistics of Universitas Negeri Semarang ${ }^{4}$ \\ Corresponding email: chamalah@unissula.ac.id ${ }^{1}$
}

\begin{abstract}
Pesantren is a very influential islamization network in Java Island. Pesantren has become a good place to grow for literature and traditions which have unique characteristics. Pesantren literature as one of uniqueness of Javanese coastal literature has never been abandoned as one of coastal pesantren literature. The unique coastal literatury work is syair or syiir. Syiir is one of sufistic poetry. The coastal literature could be used as an alternative in studying literary reading for students of PBSI Unissula. Moreover, Unissula as an islamic university should have different unique characteristics than other universities.
\end{abstract}

Keywords: local literature, coastal pesantren, teaching material, literature reading.

\section{Introduction}

Students of Sultan Agung Islamic University, mostly have pesantren academic background, consider literary tradition in pesantren should be developed in order to involve in literary appreciation. Pesantren literature is a religious literature centered in a pesantren (Pahlevi, 1998) or it can be also said that pesantren literature is a literature that was born and have flourished in pesantren (Poerbatjaraka \& Hadidjaja, 1952). Appreciation on pesantren literature has developed and been supported by publishers which has focused on publishing literary works about pesantren and santri, so the development of literary works such as novel and teen short stories also contributes to influence santris' interest to write their own experience about pesantren. For example, a novel entitled "Cahaya Cinta Pesantren" by Ira Madan, "Geni Jora" by Abidah El Khalieqy, and other short stories published online. The development of pesantren literary works is very fast, as Munawar (cited in Machsun, 2013) stating that this phenomenon is a unique complication because the existence of pesantren literature has been vacant from new creations. Without any new creations, pesantren literature actually has various forms. The variety of pesantren literature is in forms of saga (hikayat), serat, tales, poetry, narratives, romance, and verses (syiir) (Suyetnrizal, 2016).

Syiir or singir is a kind of Javanese literary art in form of a traditional poem or alike to Melayu literature (Rahmawati, 2015). Syiir is influenced by some traditional components such as thinking pattern, institution and the people who create it (William, cited in Suyetnrizal, 2016). In contrast, Istiqomah, et al., (2018) argues syiir is one of Arabic literary works that contains arabic cultural local wisdom. The local culture was built from language, technology, livelihood, social. Knowledge, relogion, and art. Furthermore, syiir as a kind of pesantren literary work has a functions and elements of beauty that need to be used (Burhanudin, 2016). Moreover, Muzakka (2006) in his research revealed three main functions of syiir, they were functions of entertainment, education and teaching, and spiritual. The entertainment function comes up for the existence of singir that is always sung in literary treasure, with or without music accompaniment. The education and teaching function comes up since singir often expresses didactic values, as Islamic moral values and complex Islamic knowledge. The spiritual function reveals because most of singir has been used as just a self-servitude to God. What most prominent from these three functions of singir according to the community is as a media of education and teaching (Muzakka, 2006). In line with the statement, Hasim (2015) said that syiir contains useful values for children character building such as respect and responsibility.

Coastal (pesisiran) pesantren literature is in fairly high numbers. It is proved by some forms of syiir such as syiir of Paras Nabi, Mawar Putih by Muhammad Nur Sanusi, Mitera Sejati by Bisri Rembang, Nasehat Konco Wadon, Sekar Cempaka, Dagang, Siti Fatimah, and Erang Erang Sekar Panjang (Nuryatin, 2018). Those 
works are considered as religious literary works for containing values of akhlak (manners), tasawuf and Islamic theology. Based on the background, the problem to be discussed is "how could literature of local coastal (pesisiran) pesantren becomes an alternative teaching materials in Literary Reading subject for students of PBSI Unissula?" The purpose of this study is to describe an alternative teaching materials in Literature Reading subject for students of PBSI Department by using local coastal (pesisiran) pesantren literature (syiir).

\section{Methods}

Method used in this research was qualitative descriptive, as a research obtaining data in forms of written words (Moleong, 2002), and philology study aiming to collect information about society in the past by providing the script that underlies studies in form of readable text for nowadays readers (Istanti, 2005). Philology study aimed to bridge over the past when the script was created and the present in which the script is read, so studies on the text was needed to result text editions that were readable by readers (Lubis, 2011).

Inventory and documentation of syiir was urgently needed for its rarity in libraries. Syiir tends to be owned by certain individual or community like pesantren. Moreover, editing on the scripts are aso needed because most of them are in Arabic-Javanese or Pegon (Muzakka, 2006; Rahmawati, 2015; and Burhanuddin 2017).

This research data was in forms of words, phrase, and clauses written on the local pesantren literature (syiir). Data source of this research was the syiir text/script as premier data, while the secondary data were the other supporting data such as syiir recording, journal, and previous relevant research.

Techniques in this research were library technique, read and note technique. Library technique was done by collecting any references relating to this research discussion, while read and note technique was done by reading verses of syiir to obtain understanding and then taking notes based on data needed in this research.

\section{Result and Discussion}

\subsection{Karakteristik Siir sebagai Sastra Lokal Pesantren Pesisiran}

Studies on Syiir have been conducted several times by different authors such as Muzakka (2006) who divided syiir/singir in various branches of science like singir Jauharat Tauhid, singir Aqidatul Awam, singir Kiyamat were grouped into science of tauhid/akidah (belief); singir akhlaq, singir mitra sejati, singir lare yatim were grouped into science of akhlaq (manners); singir fasolatan, singir sembahyang, singir wudhu, singir dagang, singir nasihat konco wadon, singir laki rabi were grouped into science of fiqh; singir paras nabi, singir siti patimah were grouped into science of tarikh (history); singir tajwid, singir bahasa arab were grouped into science of Arabic language, etc,. Those singirs were usually read in pesantren or majlis ta'lim.

Moreover, Burhanuddin (2017) revealed coastal (pesisiran) syiir script such as (1) Syiir Mitera Sejati, (2) Syiir Mawar Putih by Muhammad Nur Sanusi, (3) Syiir Nasehat Konco Wadon, (4) Syiir Sekar Cempaka, (5) Syiir Dagang, (6) Syiir Siti Fatimah, (7) Syiir Erang-Erang Sekar Panjang by Kiai Siraj, (8) Syiir Sekar Kedaton by Kiai Abi Muhammad Solih Hajawi, (9) Syiir Paras Nabi by Muhammad Ibnu Ahmad.

Based on these kinds, characteristics of syiir are (1) each stanza has similar rhyme/aaaa, (2) has constant number of syllables, (3) each line has 12-15 syllables, (4) theme of syiir is usually stories from Islamic histories or AlQuran, telling about Islamic teachings, and (5) it is always sung with certain rithmic performance and usually used by kyai in a tabligh akbar, because the language is easy to understand for common people or society (Rahmawati, 2015; Burhanuddin, 2017).

Characteristics of syiir according to Tohe (2013) are that syiir (1) could be created consciously and unconsciously, or just relies on intuitive imagination that emphasizes originality, (2) has a power of imagination and intense emotion, and (3) is an expression of feelings and emotions. In contrast to Tohe, Damani (refered to in Setyawati, 2002) said that syiir could not be created by using fictions but should be based on al-Quran, hadith, and religious books (Damami as cited in in Setyawati, 2002). Furthermore, Syiir contains moral values, advices, and education (Nuryatin, 2018). The following is an example of Syiir text based on al-Quran, hadith and religious books, as revealed in Chapter Pitutur Dhateng Sedhèrèk.Dhèrèk jaler dhèrèk éstri sampun ngantos sama mungkur dhateng napa wontenipun ingkang sampun kula matur Wontenipun anggén kula angaturi ing pitutur 
wonten Quran wonten hadis wonten kitab kang misuwur Kula matur séwu nuwun dhateng para dhèrèk kula ingkang sama merlolaken mirengaken atur kula He para dhèrèk kula mugi-mugi hanampiya atur kulak anti seneng sampung ngantos paring duka.

\subsection{Syiir as an Alternative Teaching Material in Literary Reading Subject}

Literary reading is an activity of reading literary works for the sake of appreciation as well as study or literature review. In literary works, element of beauty is very influential. The supporting elements between forms and contents in literary works do a lot influences for harmony in the works. It is in line with Tarigan (2008:141-142) saying that the beauty of a literary work is reflected by the harmony between the form and content. Furthermore, reading technique comprehension is urgently needed. Beside the suitable reading technique, a study on the reading content is also needed (Haryadi, 2014:93).

Based on the previous arguments, actually literary reading in university helps to acquire not only knowledge but also experience, character education, and how to solve daily problems. Nurhadi (2009:5) said that there were 5 purposes of reading, they were, collecting actual information, collecting information about a specific thing, appreciating papers, obtaining emotional pleasure, and killing the spare time. By reading, a person will acquire any needed information obtaining emotional pleasure, and so on. Furthermore, reading is one of important elements in studying at universities.

Reading lesson is very important for students in university for it require them not only to read a literary work in detail but also to understand it thoroughly. So, students will understand the storyline of a literary work, further meanings and reflect to other forms.

Reading comprehension in university, especially in Indonesian Language and Literature Education program explicitly comes up as Literary Reading subject. However, some reveal implicitly as subjects Aesthetic Reading, Technical Reading, and Rhytmic Reading which have competence as students could read and appreciate literary works (Chamalah, 2017). Azies \& Wasilah (1996:132) said that some things to consider in reading activity are materials, reading purpose, reading strategy, reading context, and reading comprehension.
The material is one of important element in reading.

Teaching material for Literary Reading subject is that reading literary works from various forms such as poetry, short stories, novel, drama, folklore, etc., from any generation. However, the difference here is reading literary works in form of syiir or sufistic poem containing many functions as mentioned by Muzakka (2006). Hopefully, the functions could make the Literary Reading learning more meaningful, especially for students of PBSI Unissula.

The teaching material provided was based on students need, such as by selecting relevant stanzas, then the lecturer explained about the meaning of the syiir by referring to relevant references. Students and lecturer read the syiir with relevant tone, surely by providing an example of recording before. The use of Syiir found by Burhanudin (2017) or Muzakka (2006).

\section{Conclusions}

Literary works by local coastal (pesisiran) pesantren have three main functions as entertainment, education and teaching, and spiritual functions. Materials given that are considered as good, according to Nurgiyantoro (1995:248), are those based on the development of psychology, interest, needs or the reading should relate to the purpose wanted to reach. Syiir has also typical characteristics such as each stanza has similar rhyme/aaaa, constant numbers of syllables, 12-15 syllables in each line, the theme is stories taken from Islamic history/from al-Quran/ about life based on Islamic teachings, and syiir is always sung in certain rhythmic performance.

Considering those functions and characteristics, syiir could be used as an alternative teaching material for Literary Reading subject. The material provided would be in form of verses containing meanings like what had been revealed by Muzakka (2006) and Burhanuddin (2017), then students and the lecturer together etract the meaning based on relevant libraries. Syiir reading could be done by students and lecturer together after listening to a syiir recording, so they would read the syiir correctly.

\section{References}

Azies, Furqanul dan Chaedar Al Wasilah. (1996). Pengajaran Bahasa Komunikatif. 
Bandung: Rosda Karya.

Burhanudin, Muhammad. (2016). Konservasi Nilai-Nilai Luhur Sastra Pegon: Kajian Filologis atas Syiir-Syiir di Pesisir Utara Jawa Tengah. Prosiding Seminar Nasional "Sastra, Budaya, dan Perubahan Sosial", 59-69. Surabaya: Universitas Kristen Petra.

Burhanudin, Muhammad. (2017). Nilai Humanisme Religius Syiir Pesantren. Jurnal Sastra Indonesia, 6 (1), 35-42.

Chamalah, Evi. (2017). Pengembangan Bahan Ajar Membaca Sastra Bermuatan Pendidikan Karakter untuk Membangun Budaya Literasi Kritis bagi Mahasiswa di Perguruan Tinggi. Proposal Disertasi Doktor. Semarang: Universitas Negeri Semarang.

Haryadi. (2014). "Pengembangan Buku Ajar Membaca yang Bermuatan Kreativitas Berpikir dan Nilai-Nilai Pendidikan Karakter bagi Mahasiswa Pendidikan Bahasa dan Sastra Indonesia”. Disertasi. Semarang: PPs Unnes.

Hasim, Moh. 2015. Ajaran Moral Syi'ir Ngudi Susilo dalam Membangun Karakter Anak. Analisa Journal of Social Science and Region, 22 (2), 309-319.

Istanti, Kun Zachrun. (2010). Studi Teks Sastra Melayu dan Jawa. Yogyakarta: Elmatera.

Istiqomah, Aah. 2018. Analisis Kearifan Budaya Lokal dalam Syiir Karya Halimi Zuhdy. Prosiding Seminar Nasional Bahasa Arab Mahasiswa II. Malang: Universitas Negeri Malang.

Lubis, Nabilah. 2001. Naskah Teks dan Metode Penelitian Filologi. Jakarta: Yayasan Media Alo Indonesia.

Machsum, Toha. (2013). Identitas dalam Sastra Pesantren di Jawa Timur. Jurnal Pendidikan dan Kebudayaan, 19 (3), 407 420, September 2013.

Moleong, Lexy J. (2002). Metode Penelitian
Kuantitatif. Bandung: Remaja Rosdakarya.

Muzakka, Muh. (2006). Puisi Jawa sebagai Media Pembelajaran Alternatif di Pesantren: Kajian Fungsi terhadap Puisi Singir. Makalah Kongres Bahasa Jawa IV Tahun 2006 di Semarang.

Nurhadi, et al. (2009). Dasar-Dasar Teori Membaca. Malang: Universitas Negeri Malang.

Nurgiyantoro, Burhan. 1995. Teori Pengkajian Fiksi. Yogyakarta: Gadjah Mada University Press.

Nuryatin, Agus. (2018). Literasi Sastra Lokal sebagai Upaya Meningkatkan Nilai Pendidikan Karakter bagi Mahasiswa. Materi Kuliah Pakar Prodi PBSI Unissula, Semarang 10 Juli 2018.

Pahlevi. (1998). Sastra dan Budaya Islam Nusantara, Dialektika Antarsistem Nilai. Yogyakarta: SMF Adab IAIN Sunan Kalijaga.

Poerbatjaraka, R.Ng. dan Tardjan Hadijaja. (1952). Kepustakaan Djawa. Djakarta: Djambatan.

Rahmawati, Salfia. (2015). Ajaran Islam dalam Naskah-Naskah Singir Koleksi FSUI sebagai Bentuk Persinggungan Budaya Islam Jawa:Kajian Intertekstualitas. Jurnal Al-Turas, 21 (2), 243-254.

Suyetnrizal, Moh Ahsan Shohifur. (2016). Piranti Estetika dan Nilai Pendidikan Singir Mitera Sejati dan Ngudi Susila karya Kiai Bisri Musthofa. Disertasi. Malang: Universitas Negeri Malang.

Tarigan, Henry Guntur. (2008) Membaca: sebagai Keterampilan Berbahasa. Bandung: Angkasa.

Tohe, Achmad. 2003. Kerancuan Pemahaman Antara Syi'ir dan Nadzam dalam Kesusastraan Arab. Jurnal Bahasa dan Seni, 31 (1), 38-53. 